\title{
Early to Middle Miocene marine palynology of the Colombian Caribbean Margin:
} biostratigraphic and paleoceanographic implications

Damián Cárdenas ${ }^{\mathrm{a}, \mathrm{b}}$, Francisca Oboh-Ikuenobe ${ }^{\mathrm{a}}$ and Carlos Jaramillo ${ }^{\mathrm{b}}$

Department of Geosciences and Geological and Petroleum Engineering, Missouri University of Science and Technology, Rolla, MO, USA ${ }^{\circ}$ Smithsonian Tropical Research Institute, Panama City, Republic of Panama

\section{Abstract}

Dinoflagellate cysts and acritarchs are widely used to date and reconstruct paleoenvironments in shallow to marginal marine sequences, especially in the Neogene of temperate latitudes. However, little is known about tropical regions. Here, we present an early to middle Miocene assemblage of dinocysts and acritarchs from the Cosinetas-1 Well, northern Colombia. The abundance of Spiniferites ramosus and Operculodinium centrocarpum, along with the presence of Lingulodinium machaerophorum, Spiniferites mirabilis, Polysphaeridium zoharyi, Selenopemphix nephroides and Tuberculodinium vancampoae, indicates an accumulation in warm and shallow marine environments. The peridinioid versus gonyaulacoid $(\mathrm{P} / \mathrm{G})$ ratio suggests low nutrient availability in the Cocinetas Basin during the early Neogene. In contrast, modern shallow waters along the Guajira Peninsula are productive except in the eastern part where coastal upwelling is perturbed by warm water inflow from the Lake Maracaibo. In addition, the biostratigraphic range proposed for Achomosphaera alcicornu in equatorial latitudes is constrained to the Rupelian according to Williams et al. (2004); however, the continuous presence of $A$. alcicornu in the Cosinetas-1 Well extends its last appearance datum in the tropical Americas to at least the early Miocene.
Geologic Framework

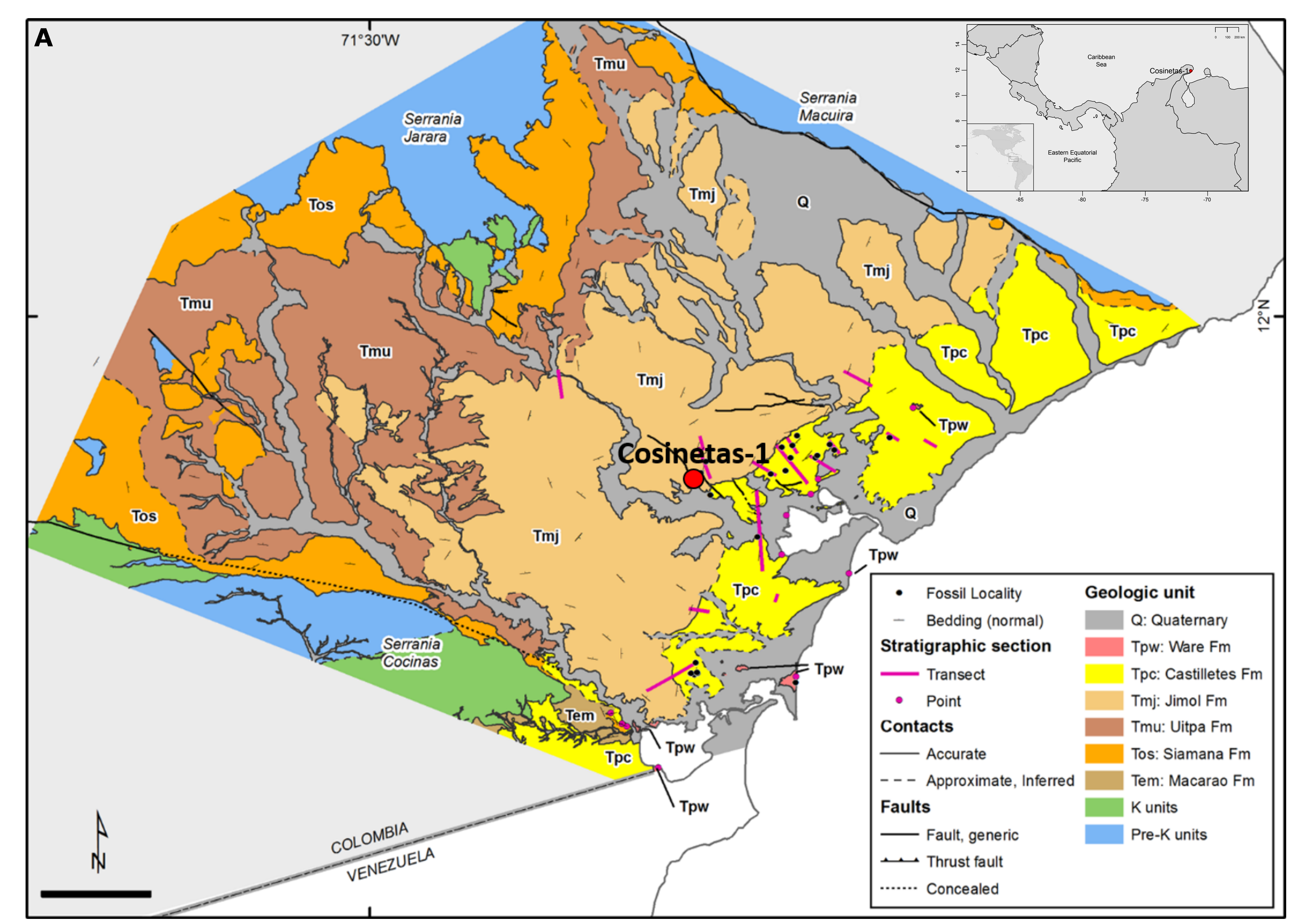

igure 1. Regional location, geology and lithostratigraphy of the Cocinetas Basin and the Cosinetas-1 Well, La Guajira, northern Colombia. Modified from Moreno et al. (2015). A Geologic map of the Cocinetas Basin. B Lithostratigraphic
composite ditch-cutting samples.

References

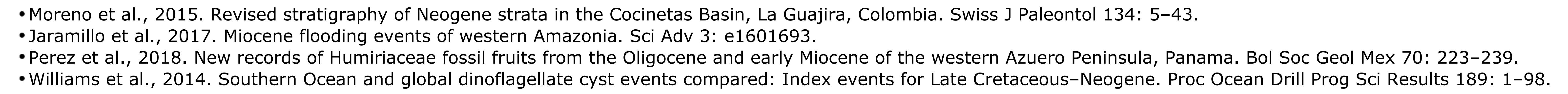

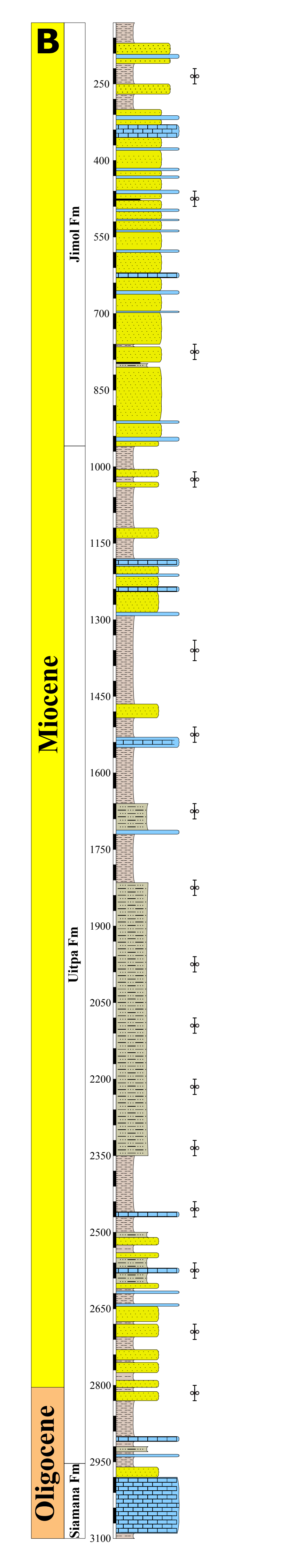

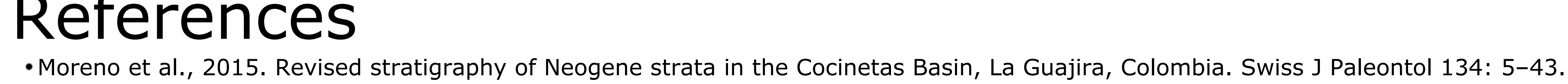

Biostratigraphy and Paleoproductivity

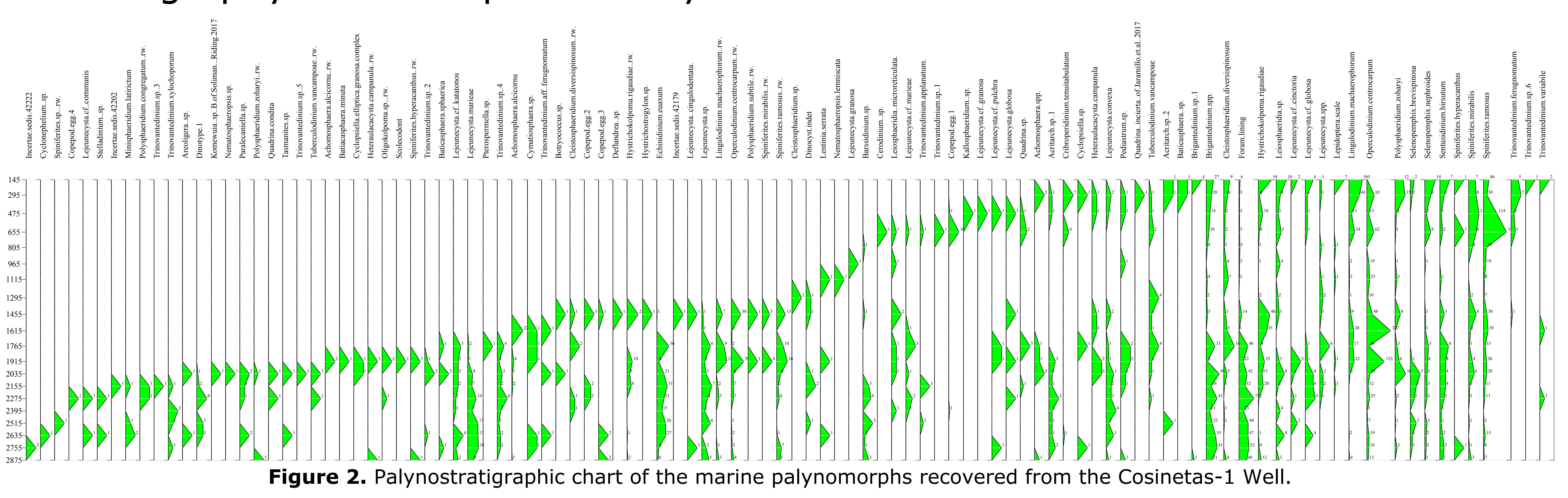
Biostratigraphic markers

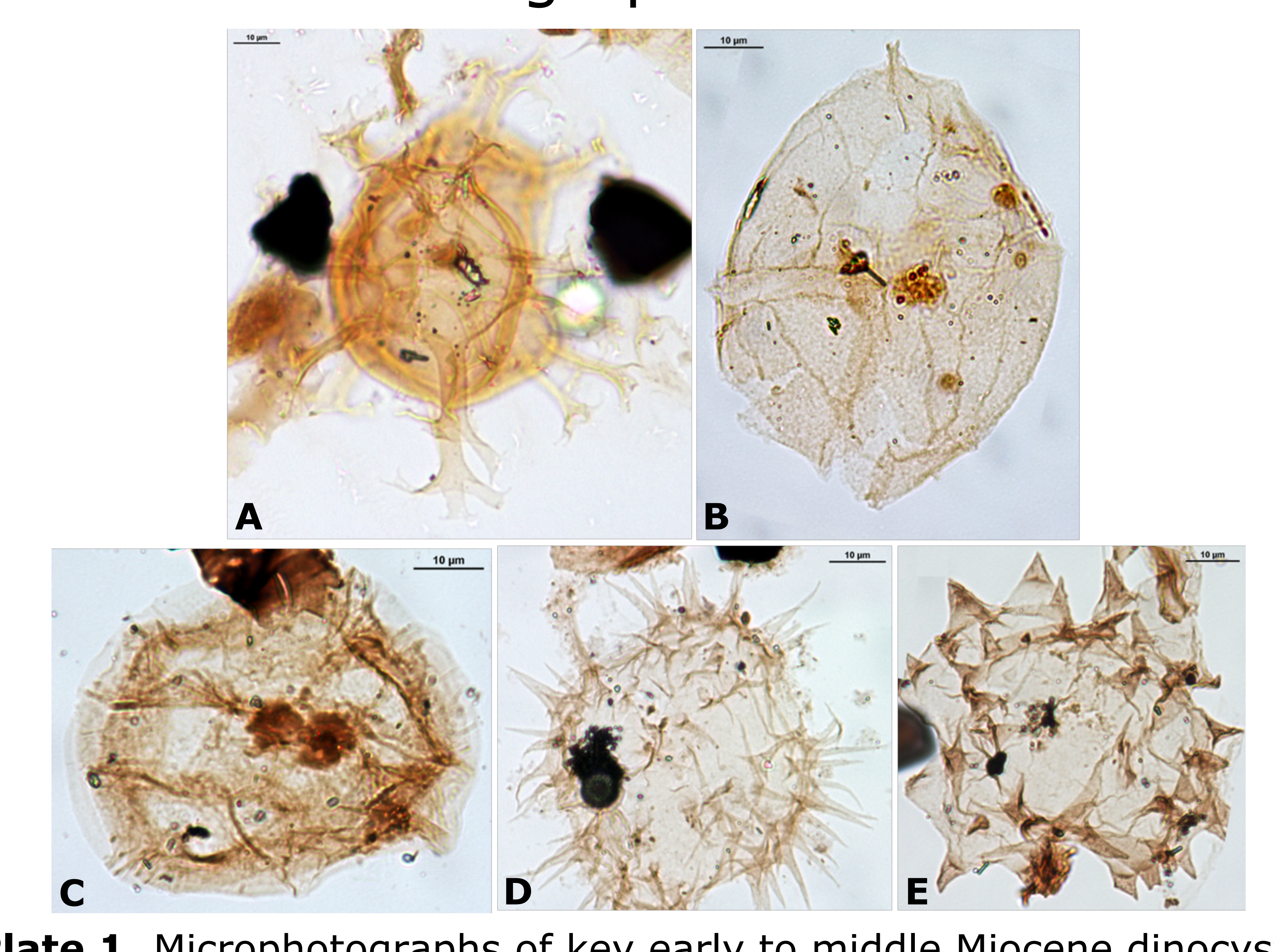

Plate 1. Microphotographs of key early to middle Miocene dinocysts
and acritarchs from the Cosinetas-1 Well. A. Achomosphera alcicorn

The stratigraphic range of Achomosphaera alcicornu in equatorial latitudes is restricted to the Rupelian (Williams et al. 2014); however, our results indicate that the LAD for this key biostratigraphic taxon in the Caribbean

extends at least to the Aquitanian. Recent biostratigraphic analyses of the late Oligocene-early Miocene of Panama by Perez et al. (2018) support a younger A. alcicornu LAD for the tropical Americas. Further detailed palynological analyses of equatorial sections are needed to improve the stratigraphic ranges of marine palynomorphs in low latitudes. B. Cribroperidinium tenuitabulatum C. Heteraulacacysta campanula
D. Quadrina condita E. Quadrina "incerta" of Jaramillo et al. 2017.
Paleoenvironmental indicators

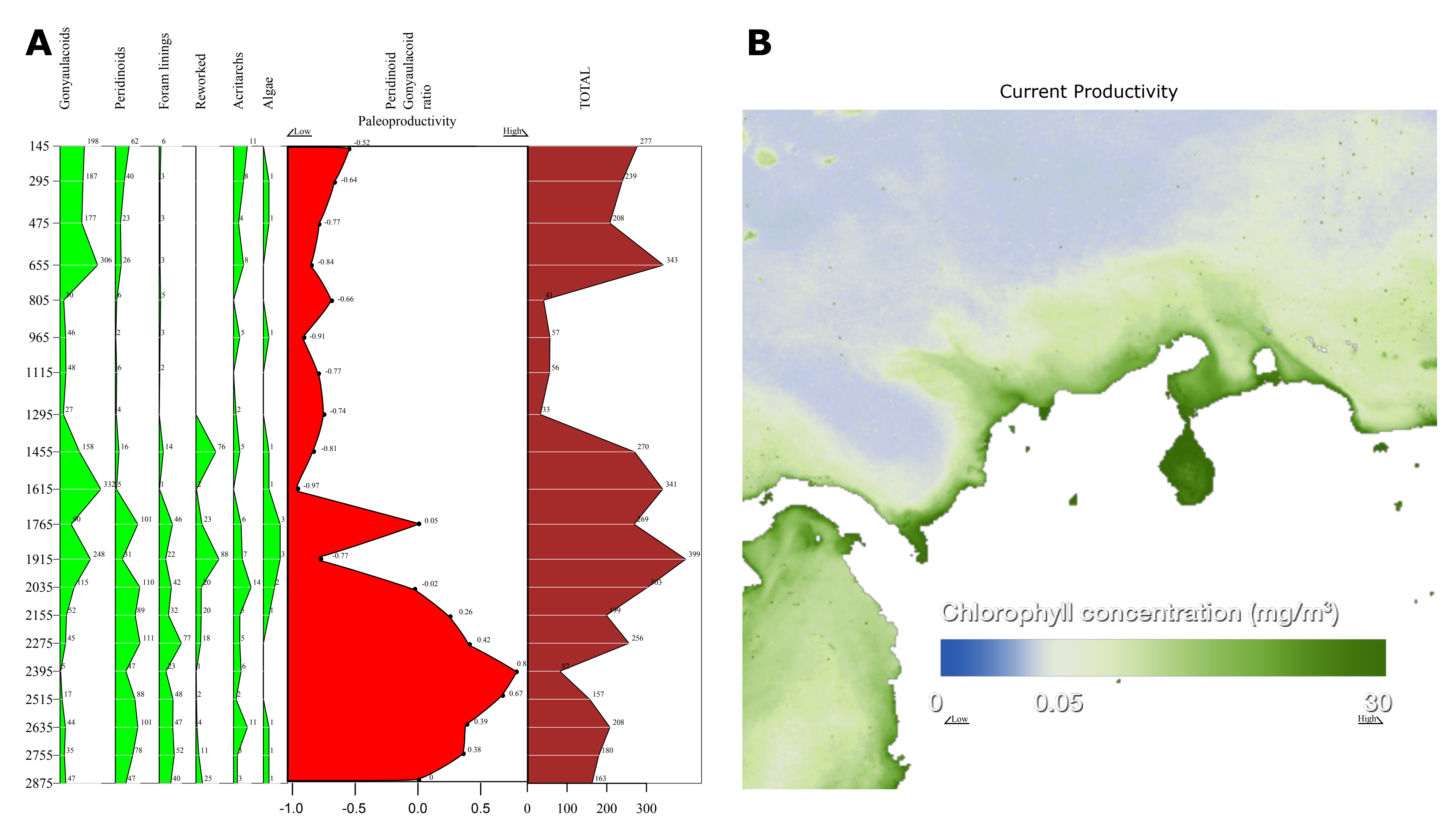

Figure 3. Early to middle Miocene paleoproductivity reconstruction of the Cocinetas Basin (A) in relation to current productivity (B).

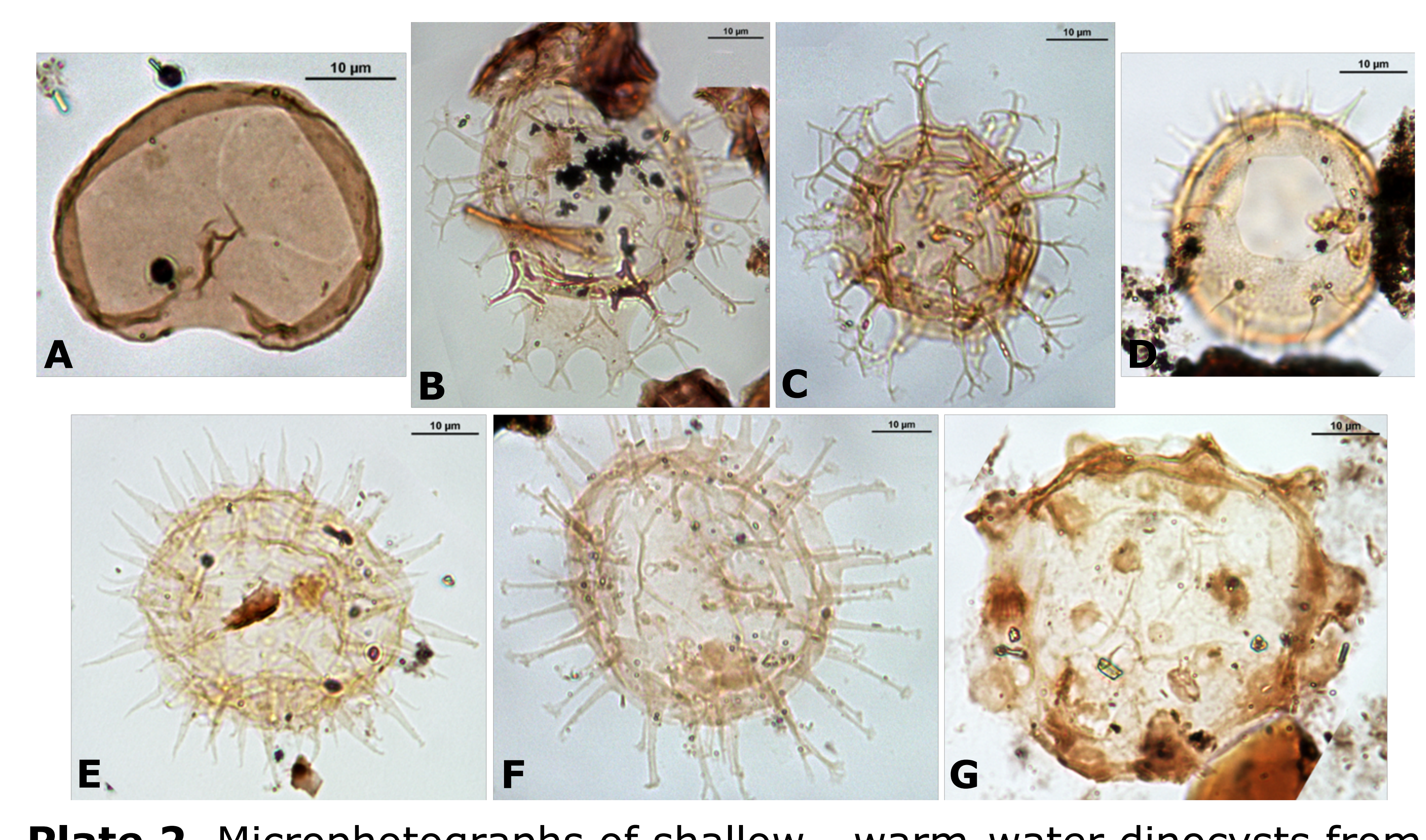

Plate 2. Microphotographs of shallow-, warm-water dinocysts from mirabilis C. Spiniferites ramosus $\mathbf{D}$. Operculodinium centrocarpum E. Lingulodinium machaerophorum F. Polysphaeridium subtile 